\title{
QUALIFICATION OF STAINLESS STEEL FOR OTEC HEAT EXCHANGER TUBING
}

\author{
F. L. LaQue
}

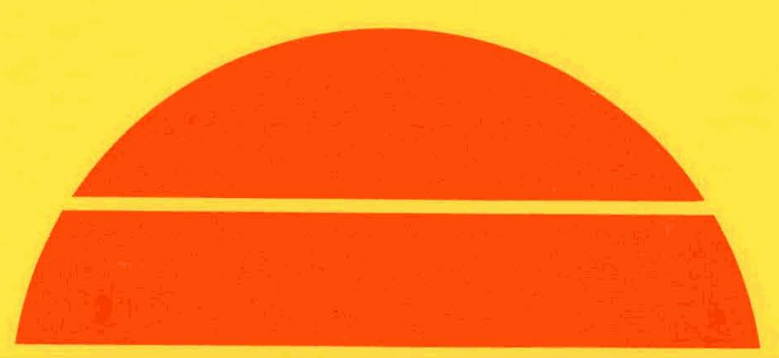

\section{MASTER}

Argonne National Laboratory 9700 South Cass Avenue Argonne, Illinois 60439
Prepared for the

U. S. Department of Energy Division of Central Solar Technology under Contract W-31-109-Eng-38 


\section{DISCLAIMER}

This report was prepared as an account of work sponsored by an agency of the United States Government. Neither the United States Government nor any agency Thereof, nor any of their employees, makes any warranty, express or implied, or assumes any legal liability or responsibility for the accuracy, completeness, or usefulness of any information, apparatus, product, or process disclosed, or represents that its use would not infringe privately owned rights. Reference herein to any specific commercial product, process, or service by trade name, trademark, manufacturer, or otherwise does not necessarily constitute or imply its endorsement, recommendation, or favoring by the United States Government or any agency thereof. The views and opinions of authors expressed herein do not necessarily state or reflect those of the United States Government or any agency thereof. 


\section{DISCLAIMER}

Portions of this document may be illegible in electronic image products. Images are produced from the best available original document. 
The facilities of Argonne National Laboratory are owned by the United States Government. Under the terms of a contract (W-31-109-Eng-38) between the U. S. Energy Research and Development Administration, Argonne Universities Association and The University of Chicago, the University employs the staff and operates the Laboratory in accordance with policies and programs formulated, approved and reviewed by the Association.

\section{MEMBERS OF ARGONNE UNIVERSITIES ASSOCIATION}

The University of Arizona Carnegie-Mellon University Case Western Reserve University The University of Chicago University of Cincinnati Illinois Institute of Technology University of Illinois Indiana University Iowa State University The University of Iowa
Kansas State University The University of Kansas Loyola University Marquette University Michigan State University The University of Michigan University of Minnesota University of Missouri Northwestern University University of Notre Dame
The Ohio State University Ohio University

The Pennsylvania State University Purdue University

Saint Louis University

Southern Illinois University The University of Texas at Austin Washington University Wayne State University The University of Wisconsin

\section{NOTICE}

This report was prepared as an account of work sponsored by the United States Government. Neither the United States nor the United States Energy Research and Development Administration, nor any of their employees, nor any of their contractors, subcontractors, or their employees, makes any warranty, express or implied, or assumes any legal liability or responsibility for the accuracy, completeness or usefulness of any information, apparatus, product or process disclosed, or represents that its use would not infringe privately-owned rights. Mention of commercial products, their manufacturers, or their suppliers in this publication does not imply or connote approval or disapproval of the product by Argonne National Laboratory or the U. S. Energy Research and Development Administration.

Printed in the United States of America Available from

National Technical Information Service

U. S. Department of Commerce 5285 Port Royal Road

Springfield, Virginia 22161

Price: Printed Copy $\$ 4.50$; Microfiche $\$ 3.00$ 
Distribution Category:

Ocean Thermal Energy

Conversion (UC-64)

ANL/OTEC-001

Argonne National Laboratory

9700 South Cass Avenue Argonne, Illinois 60439

QUALIFICATION OF STAINLESS STEEL FOR OTEC HEAT EXCHANGER TUBES

F. L. LaQue

Claridge Drive

Verona, New Jersey 07044

January 1979

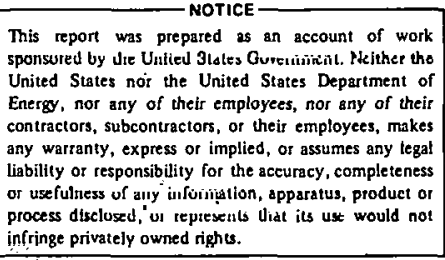
process disclused, 'ur represents Ulat its use would not infringe privately owned righes. 
THIS PAGE

\section{WAS INTENTIONALLY LEFT BLANK}


TABLE OF CONTENTS

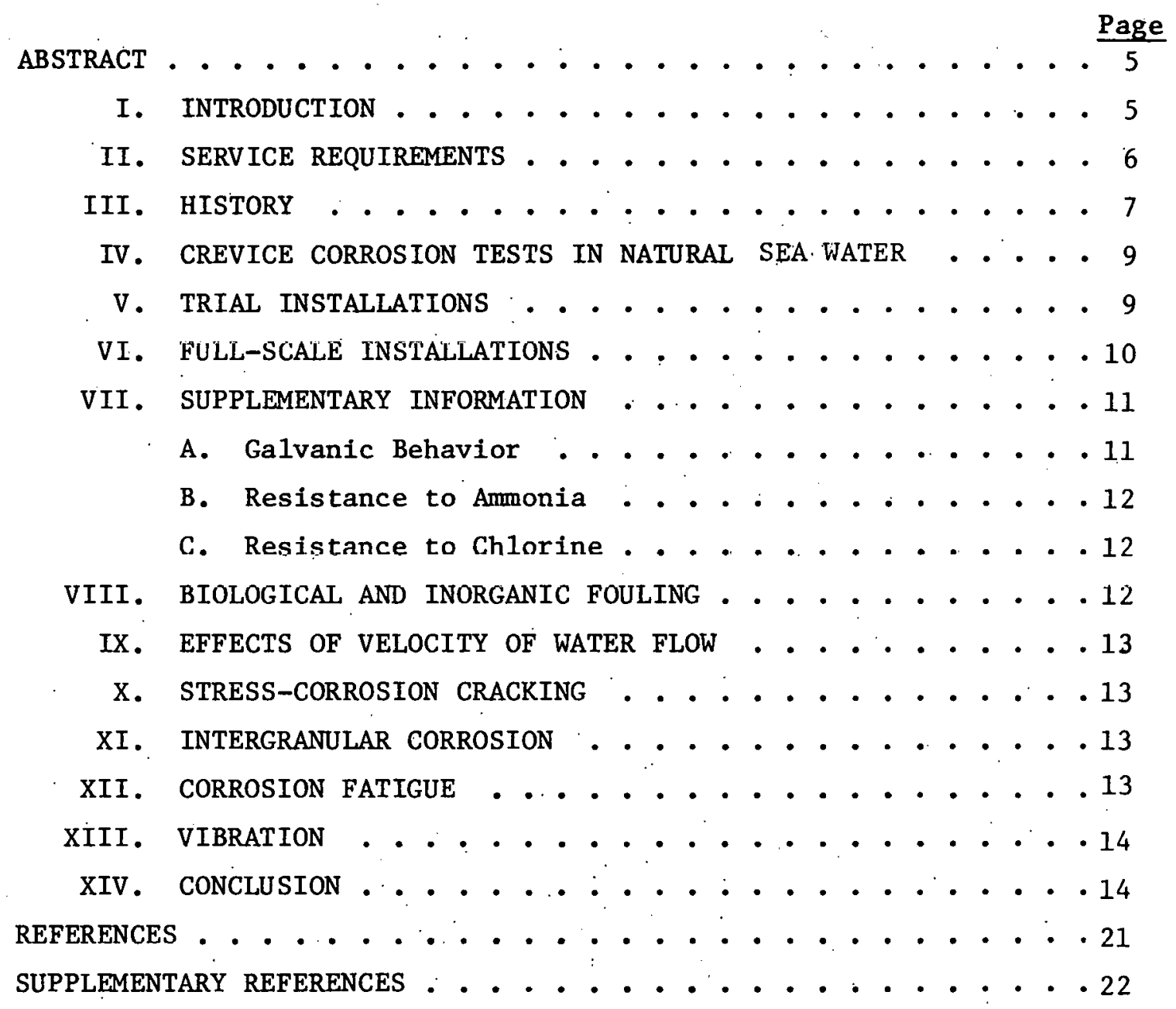


THIS PAGE

\section{WAS INTENTIONALLY LEFT BLANK}


QUALIFICATION OF STAINLESS STEEL FOR

OTEC HEAT EXCHANGER TUBES

F. L. LaQue

\begin{abstract}
This paper reviews the history of the AL-6X alloy and examines its credentials as a candidate for use as tubing in Ocean Thermal Energy Conversion Heat Exchangers. Qualification is based on results of accelerated tests using ferric chloride for resistance to crevice corrosion and pitting, long-time crevice corrosion and pitting tests in natural sea water and anticipated resistance to attack by ammonia and mixtures of ammonia and sea water.
\end{abstract}

Since the alloy has no natural resistance to fouling by marine organisms, it must be able to accommodate action to prevent fouling by chlorination or to remove it by mechanical cleaning techniques or appropriate chemical cleaning methods.

The satisfactory behavior indicated by the various accelerated and long-time corrosion tests has been confirmed by excellent performance of several million feet of tubing in condensers in coastal power plants.

Early evaluation tests demonstrated the need for proper heat treatment to avoid the presence of a sigma phase, which promoted severe pitting of some, but not all, specimens in tests in natural sea water.

The available data qualify the AL- $6 \mathrm{X}$ alloy as being a satisfactory alternate to titanium for tubes in OTEC heat exchangers.

\title{
I. INTRODUCTION
}

The purpose of this paper is to examine the credentials of highly alloyed stainless steel materials as candidates for tubing in OTEC heat exchangers.

This class of material is represented primarily by the alloy known as AL-6X. AL-6X is the trade name of a product of the Allegheny Ludlum Steel Company. The nominal composition of $\mathrm{AL}-6 \mathrm{X}$ is $24 \% \mathrm{Ni}, 20 \% \mathrm{Cr}$ and $6 \% \mathrm{Mo}$.

Other alloys that appear to be worthy of consideration include one contalning $26 \%$ chromium and $1 \%$ molybdenum, and others containing $25 \%$ or more chromium with various percentages of molybdenum and nickel. These other alloys have performed well in some screening tests and in exposure to natural sea water. Results of trial installations are not yet available.

At the present time, the AI- $6 \mathrm{X}$ alloy has been qualified above the other alloys by reason of more extensive evaluation and, more importantly, by 
successful large scale practical use in service pertinent to OTEC heatexchanger applications. Consequently, this paper will concentrate on qualification of $\mathrm{AL}-6 \mathrm{X}$ as a representative of alloys of similar composition that may be offered by other suppliers for use as tubing in OTEC heat exchangers.

This effort is needed in view of questions that have been raised recently based on a few instances of poor performance of the alloy in evaluation tests and of a few tubes in a particular service installation.

As will be pointed out later in some detail, the poor performance in certain laboratory evaluation tests and in one test in natural sea water was due to an improper heat treatment used in the early stages of the alloy development. This has been corrected in recent and current production practice.

The service failure was associated with failure of another component, a steam baffle, which brought the outer surfaces of the tubes that failed in a power plant condenser into contact with steam at a very high temperature without adequate flow of cooling water inside the tubes. Other materials being considered for OTEC tubing, such as copper alloys, alluminum and titanium, would not have been able to survive the unusual conditions that caused failure of the $\mathrm{AL}-6 \mathrm{X}$ tubes in this instance.

The data to be obtained from accelerated screening tests, long-time tests in sea water, trial installations, service experience and supplementary pertinent information will provide additional evidence as to the potential utility of alloys with the AL-6X composition. These data will also support continued interest in future qualification of other highly alloyed stainless steels that have shown promise in exploratory tests. No consideration need be given the ordinary grades of stainless steel in the 300 and 400 series.

\section{SERVICE REQUIREMENTS}

The principal requirements for corrosion resistance of tubing for OTEC heat exchangers are as follows:

1. Resistance to general wastage, pitting and crevice corrosion in sea water in a temperature range from 5 to $38^{\circ} \mathrm{C}$ with oxygen concentrations from near zero to saturation at flow velocities ranging from stagnation to at least 8 feet $(2.4 \mathrm{~m})$ per second.

2. Resistance to sea water in the presence of concentrations of chlorine that may be used to control fouling.

3. Resistance to abrasion by devices that may be used to remove fouling.

4. Resistance to ammonia, alone or mixed with sea water, expected to be used as the fluid for power generation. 
The AL-6X alloy is related to an alloy originally identified as IN -748 . The latter alloy, covered by U.S. Patent 3,547,625, was developed in the research laboratories of the International Nickel Company, Inc. The original objective was to provide a material for high strength wire rope that could be used in marine environments without failures from crevice corrosion encountered to an intolerable extent in wire rope made from the commercial 300 series grades of stainless steel.

Another objective was to provide an alloy substantially cheaper than such alloys as Inconel* 625 and Hastelloy** $C$ that had the necessary strength and corrosion-resistant properties but were considered to be too expensive for most wire rope applications.

Coincidentally, manufacturers of welded, thin-wall Types 304 and 316 stainless steel tubes had found that, although these alloys were economically attractive and performed well in power plant condensers cooled with fresh water, they were not adequate for use in condensers cooled with salt water.1-4 The principal cause of failure was corrosion in crevices formed by deposit of solids under conditions of interrupted flow without adequate cleaning.

The IN-748 alloy came to the attention of fabricators of stainless steels, including the Allegheny Ludlum Steel Company. They were interested in developing an alloy that would not be subject to corrosion in crevices under deposits on salt-water-cooled condenser tubes made of Types 304 and 316 stainless steel.

Using the composition of the IN -7.48 alloy as a guide, Allegheny Ludlum modified the alloy to suit their production practices while maintaining the required resistance to crevice corrosion and pitting. The nominal composition of the IN-748 alloy was $27 \% \mathrm{Ni}, 20 \% \mathrm{Cr}$ and $8.5 \%$ Mo. The resultant AL- $6 \mathrm{X}$ alloy contains $24 \% \mathrm{Ni}, 20 \% \mathrm{Cr}$ and $6 \% \mathrm{Mo}$.' Comparative tests of the two alloys have shown that the AL- $6 \mathrm{X}$ modification of IN-748 retains the resistance to pitting and crevice corrosion in sea water that was the target for the develupment of Llie IN-748 alloy.

In the course of the alloy development program, it was found necessary to avoid the presence of an intermetallic sigma phase rich in chromium and molybdenum. This impaired resistance to corrosion in the alloy-depleted zones adjacent to the sigma. 5

Poor performance attributed to sigma varied depending on the amount of sigma present and, particularly, on its most damaging location at grain boundarles. It also varied with the method of test. Sigma phace wae responsible for poor performance in accelerated laboratory tests using ferric chloride. However, it was not found to be harmful in some early trial

*Trade Mark, International Nickel Co., Inc., New York, NY. **Trade Mark, Cabot Corporation, Stellite Division, Kokomo, IN. 
installations in which properly heat treated material performed satisfactorily despite the presence of a sigma phase.

An example of what has been described was provided by tests of the AL-6X alloy by the U.S. Naval Research Laboratory at Key West, Florida. 6 Specimens exposed for 218 days under conditions of quiet immersion suffered crevice corrosion to a depth of about 0.01 inch $(254 \mu \mathrm{m})$.

Corrosion specimens were also exposed to sea water flowing at a rate of $180 \mathrm{ml} / \mathrm{min}$ in a test cell at Key West Laboratory. Under these conditions, an AL-6X specimen exposed for 218 days was perforated 0.065 in. (1651 $\mu \mathrm{m})$ while companion specimens exposed in a test cell for 552 days suffered practically no crevice corrosion.

It seems likely that the absence of crevice corrosion of the AL-6X alloy in the much longer test period was no more than an example of the statistical probability feature of the incidence of crevice corrosion of stainless steels. Such attack may not occur within all crevices of test specimens containing several crevices.

Incidentally, specimens of a $26 \% \mathrm{Cr} 1 \%$ Mo alloy with a thickness of 0.06 in. $(1524 \mu \mathrm{m})$ suffered crevice corrosion to a depth of $0.05 \mathrm{in}$. $(1270 \mu \mathrm{m})$ in the quiet immersion test at Key West and perforated in the 552-day test in the flowing water cell.

The effects of sigma phase and its elimination by proper heat treatment of the AL-6X alloy were demonstrated by crevice corrosion tests in hot sea water at Harbor Island, North Carolina. The test used was the multiple crevice technique developed by D. B. Anderson. 7

In this test, 20 crevices are created on each side of a $4 \times 6$ in. ( $100 \times 150 \mathrm{~mm}$ ) flat specimen by pressing a serrated Delrin washer against the surface of the metal. The ratio of shielded-to-freely exposed area is 1 to 85 .

After exposure, the depths of attack at any of the 40 crevices are measured and subjected to statistical analysis of the frequency and depths of attack.

This approach 1s responsive to observations that crevice corrosion of stainless steels in sea water is a matter of probability as well as intensity. The probability factor was illustrated dramatically in the tests at Key West by Lennox and Peterson, 6 as described previously. Results of such tests showing the effects of annealing temperature are indicated in Table $\mathrm{I}$.

Several types of accelerated screening tests have been used in the development of stainless steels that will resist pitting and crevice corrosion. Most important of these are tests using ferric chloride.

An early ferric chloride test was that used by H. Smith. ${ }^{8}$ The specimens used in this test did not include any crevices. Subsequent modifications using specimens with crevices have been found to be more discriminating in predicting resistance to pitting and crevice corrosion under conditions of long-time exposure to natural sea water. 
In the course of the development of the IN-748 and AL-6X alloys, specimens have been subjected to ferric chloride tests to demonstrate their resistance to crevice corrosion and their superfority in this respect to such less resistant alloys as Types 304 and 316 stainless steel. Typical results* of such tests are shown in Table II.

Another ferric chloride test to measure resistance to crevice corrosion was developed by R. J. Brigham. 9,10 This was based on running the test at a series of increasing temperatures and observing the highest temperature at which a significant increase in extent of crevice corrosion had occurred. Results, as reported by Bond et al., 11 are shown in Table III.

This test showed the improved resistance to crevice corrosion of the AL-6X alloy and the other highly alloyed compositions over the Type 316 alloy.

Another approach to screening is an electrochemical test ${ }^{12}$ in which current is applied to a specimen in a series of increasing potentials. Observations of the amount of current that is passed can define what is called a "breakthrough" or "rupture" potential coincident with a substantial increase in current. The higher this potential the greater the expected resistance to pitting and creyice corrosion. Representative results of such tests are shown in Table IV. 13

\section{CREVICE CORROSION TESTS IN NATURAL SEA WATER}

Although results of ferric chloride and other screening tests indicated that the AL-6X alloy would have a high level of resistance to crevice corrosion and pitting in natural sea water, it was necessary to confirm this expectation by long-time tests in the natural environment using the Anderson multiple crevice technique.

Specimens of the AL-6X alloy were exposed at Harbor Island, North Carolina for five years with results as shown in Table $V$.

The AL-6X specimens from this five-year test were found to be free of pitting as well as free of corrosion in the crevices. Also, no localized corrosion was found under the several varieties of fouling organisms that became attached to the alloy during the test period.

\section{TRIAL INSTALLATIONS}

Encouraged by the favorable results of accelerated laboratory screening tests and exposures to natural sea water, trial lots of welded AL-6X tubes and commercial Types 304,316 and 216 stainless steel were placed in service in operating power plant condensers at New Haven, Connecticut and 01dsmar, Florida. The Connecticut location had been the site of failures of Type 316 stainless tubes by crevice corrosion under deposits.

In the Connecticut tests, some of the 216 and AL-6X tubes were installed with inlet end restrictions th reduce the flow velocity from the normal 8 feet

*Results of similar tests supporting the same conclusion can be found in appended supplementary references. 
$(2.4 \mathrm{~m})$ per second to 0.1 foot $(30 \mathrm{~mm})$ per second. This was done to prevent deposition of solids, which had been found to have been the principal factor in the failure of Type 316 tubes in this service.

Withdrawals of test tubes after one and three years disclosed serious pitting in the Types. 304 and 316 tubes but none in the 216 and AL-6X tubes in both the Connecticut and Florida tests.

After six years, the single remaining 304 tube in the Florida installation contained many small pits. The 316 tubes showed many smaller pits. Both the 216 and AL-6X tubes tested with unrestricted flow remained free from pits at the end of six years at both locations.

The partially restricted 216 tubes in the New Haven test showed larger pits than the unrestricted Type 316. The partially restricted AL-6X tubes showed some light but insignificant attack. There was no attack in the crevice under the plug used to restrict flow.

The AL-6X tubes used in these trial installations had been made at a time when the annealing cycle did not avoid the presence of the sigma phase shown to be harmful in accelerated laboratory tests.

Samples from the tubes used in the trial installations were re-heat treated in accordance with the improved current production practice and subjected to the laboratory crevice corrosion screening test for comparison with samples of the test tubes in their original improperly heat treated condition. The properly heat treated material performed satisfactorily in the crevice corrosion test.

It would appear that the crevice corrosion screening test is much more drastic toward the AL- $6 \mathrm{X}$ alloy than the restricted flow conditions established in the Connecticut trial installation designed to promote pitting under deposited solids.

\section{FULL-SCALE INSTALLATIONS}

By the end of 1978, several million feet of AL-6X tubes had been installed in salt-water-cooled condensers in coastal power plants in the United States. 'These installations are shown in lable VI. In addition to these full-scale installations, thousands of $\mathrm{AL}-6 \mathrm{X}$ inserts are being used by several power companies to extend the life of brass tubes that have suffered inlet end erosion.

With the exception of one instance to be described in detail, no trouble has been encountered with the millions of feet of AL-6X tubes in the installations listed in Table VI. This one exception was the result of abnormal circumstances encountered early in 1977 at the United Illuminating Co. station in Bridgeport, Connecticut.

As a result of failure of a steam impingement baffle in front of six AL-6X tubes, $7 / 8$ inch $(21 \mathrm{~mm})$ diameter, 0.028 inch $(0.7 \mathrm{~mm})$ wall, in an upper row of the condenser, high velocity steam bled from a heater drain vent or a 
gland was dumped into the condenser through a 1-1/2 to 2 -inch line in a temperature range of from $600\left(316^{\circ} \mathrm{C}\right)$ to $1000^{\circ} \mathrm{F}\left(538^{\circ} \mathrm{C}\right)$. The steam ruptured the baffle and impinged directly on the tubes to cause the failure.

None of the other $7,556 \mathrm{AL}-6 \mathrm{X}$ tubes that were installed in this condenser in 1975 failed at the time of the incident described, or since.

Any of the other materials being considered for OTEC heat exchangers would have been similarly damaged by the abnormal conditions that caused the failure of the AL- $6 \mathrm{X}$ tubes.

The normal operating conditions in the condenser at the Bridgeport station are particularly severe, since they involve peaking service with daily shut down and start ups. The steam velocities are high but have not led to any failures from vibration. The steam contains some ammonia from the feed-water treatment.

\section{SUPPLEMENTARY INFORMATION}

Qualification of a material for use in O'TEC heat exchangers requires consideration of a number of other factors covered by the following discussions.

A. Galvanic Behavior

The AL-6X alloy occupies a position in a galvanic series in sea water shown by Table VII.

It can be expected that the AL-6X alloy will not be subject to acceleration of corrosion by galvanic contact with any of the materials with which it may become associated in OTEC systems.

The AL-6X alloy could accelerate corrosion of aluminum, steel or other less noble metals if coupled to them. The extent of this galvanic effect would be about the same as that expected from similar combinations involving titanium and copper-nickel alloys.

In new condensers, it would be desirable to use steel tube plates clad with a stainless steel of high molybdenum content such as Jessop* 700 containing $21 \%$ chromium, $25 \%$ nickel and $4.5 \%$ molybdenum if steel clad with the AL-6X composition should not be available. Second choices would be cladding with Incoloy** 825 or Carpenter $20 \mathrm{Cb}$. The use of such alloy clad steel tube plates would facilitate'seal welding of tubes, which would be desirable to prevent leakage of ammonia.

AL-6X tubes would be able to tolerate copper in corrosion products from copper alloys, such as the 90:10 copper-nickel alloy 706 that might be used upstream to take advantage of its antffouling properties, in screens or piping.

\footnotetext{
*Trade Mark, Jessop Steel Co., Washington, PA.

**Trade Mark, International Nickel Co., Inc., New York, NY.

trrade Mark, Carpenter Technology Corp., Reading, PA.
} 


\section{B. Resistance to Ammonia}

Since AL-6X is a ferrous alloy, it can be expected to be free of corrosion by ammonia. Leakage of ammonia into sea water, or vice versa, would not be expected to impair resistance to attack by either. AL-6X has been reported to be resistant to ammonia. 14

Less highly alloyed stainless steels have been used successfully as tubes in heat exchangers involving exposure to ammonia.

\section{Resistance to Chlorine}

There have been no reported problems attributable to the use of chlorine for controlling fouling in heat exchangers in which stainless steels less highly alloyed than AL-6X have been used. Because of its higher molybdenum content, the AL-6X alloy would be expected to have superfor resistance to chlorinated sea water. This was confirmed also by results of a laboratory screening test in which the AL-6X composition was found not to be affected by exposure to a $5 \%$ solution of sodium hypochlorite at $50^{\circ} \mathrm{C} .15$

\section{BIOLOGICAL AND INORGANIC FOULING}

Since the AL-6X alloy is inert in sea water, it does not resist fouling by macroorganisms or bacterial slimes. It would be necessary to remove such fouling from heat exchanger tubes by mechanical or chemical cleaning or prevent fouling by chlorination or other treatment of the water.

Mechanical cleaning of stainless steel heat exchanger tubes, e.g., by the Amertap system, has been employed without damage to the tubes. 4 There is no record of the use of the Amertap system with AL-6X tubes, but no damage to such tubes need be anticipated.

The absence of corrosion products and maintenance of a smooth surface on AL-6X tubes should contribute to heat transfer and facilitate mechanical cleaning.

The resistance of the AL- $6 \mathrm{X}$ alloy to a broad range of chemicals should broaden the choice of chemical cleaning agents, if this approach to maintenance of heat transfer should be adopted.

Since the AL-6X alloy will not corrode, there will be no electrical. currents from local corrosion action that might trigger deposition of calcium and so forth from supersaturated water. This would give the AL-6X alloy an additional advantage over materials such as aluminum which is less resistant to corrosion.

\section{EFFECTS OF VELOCITY OF WATER FLOW}

AL-6X tubes are being used successfully. in power plant condensers with a design water velocity of 8 feet $(2.4 \mathrm{~m})$ per second. This also was the velocity encountered in the successful trial installations previously 
described. Although the alloy could withstand higher flow velocities, these are not likely to be used in OTEC heat exchangers.

In the evaluation of the alloy for other possible applications in sea water, specimens were exposed to sea water flowing at velocities up to 140 feet $(43 \mathrm{~m})$ per second. The results are shown in Table VIII.

Resistance to deterioration from impingement of high velocity sea water would be an advantage for the AL-6X alloy, if sea water jets were to be used for cleaning OTEC heat transfer surfaces.

As noted previously, the AL-6X alloy will tolerate the even more dangerous conditions of exposure to slowly moving sea water in partially obstructed tubes, under deposits in tubes, and under attached marine organisms.

\section{STRESS-CORROSION CRACKING}

The temperatures to be encountered in OTEC heat exchangers are well below those at which chloride stress-corrosion cracking of austenitic stainless steels has been observed [above $140^{\circ} \mathrm{F}\left(60^{\circ} \mathrm{C}\right)$ ].

The AL-6X alloy was found to be susceptible to stress-corrosion cracking in boiling concentrated magnesium chloride, which is considered to be the most aggressive medium for promoting stress-corrosion cracking of austenitic stainless steels. Other chlorides, including sea water, are much less aggressive.

The relatively high nickel content of the AL-6X composition improves resistance to chloride stress-corrosion cracking. 16 This improvement was demonstrated by freedom from cracking in boiling $20 \%$ sodium chloride. 14

\section{INTERGRANULAR CORROSION}

The AL-6X alloy is made with a sufficiently low carbon content (less than $0.03 \%$ ) to avoid sensitization to intergranular corrosion that results from precipitation of chromium carbides in austenitic stainless steels.

Another form of sensitization caused by formation of a sigma phase, discussed previously, is avoided by appropriate heat treatment used in the production of the alloy.

\section{CORROSION FATIGUE}

No data are available on the corrosion fatigue properties of the AL-6X alloy. However, its high resistance to pitting, which otherwise could serve to create local stress-raising notches, can be expected to give the alloy an advantage over metals less reslstant to local attack. 


\section{VIBRATION}

There have been no instances of failure of AL-6X tubes that replace copper alloys. In these cases, the spacing of the tube supports had been designed for thicker-walled tubes of copper alloys. In new installations of AL-6X tubes, the spacing of the tube supports will, presumably, be related properly to the properties of the AL-6X alloy and the dimensions of the tubes.

Choice of the AL-6X alloy in preference to titanium to replace copper alloys in condensers with tube supports designed for the copper alloys has been reported ${ }^{14}$ to have been based on vibration-related failures of thinwall titanium tubes in such installations.

The higher modulus of elasticity of the AL-6X alloy $\left(29 \times 10^{6}\right)$, as compared with titanium $\left(15 \times 10^{6}\right)$, should be advantageous with respect to vibratinn.

\section{CONCLUSION}

The evidence compiled in this review supports continuing consideration of the AL-6X alloy as a desirable material for tubing in OTEC heat exchangers.

The high-purity high chromium alloys containing from 1 to $4 \%$ molybdenum have performed well enough in evaluation tests to warrant further attention. To date, the number of trial or full-scale installations has not been adecuate to provide a record of condenser service experience for the chromium alloys that is comparable to that of the AL-6X alloy.

As noted in its history, the AL-6X alloy is a modification of the INCO IN-748 alloy. Other alloy producers may, in the future, offer either the original IN-748 composition or a modification (contalning at least $6 \%$ molybdenum) that could be expected to perform well in OTEC heat exchangers.

In a more general way, it has been found that alloys likely to demonstrate adequate resistance to pitting and crevice corrosion haye chromium and molybdenum contents to the right of the line in Figure 1.17 The alloy in this figure, identified as Sea-Cure,* has a nominal composition of $26 \%$ $\mathrm{Cr}, 3 \%$ Mo and $2.5 \% \mathrm{Ni}$.

None of the commercial stainless steels in the 300 or 400 series have the level of resistance to pitting and crevice corrosion required for use in OTEC heat exchangers.

※Trade Mark, Colt Industries, Inc., Crucible Materials Research Center, Pittsburgh, PA. 
TABLE I. Effect of Heat Treatment on Resistance of AL-6X to Crevice Corrosion in Sea Water at Harbor Island, North Carolina for 30 .Days at $50^{\circ} \mathrm{C}^{\mathrm{a}}$

\begin{tabular}{lccc}
\hline $\begin{array}{c}\text { Annealing } \\
\text { Temperature }\end{array}$ & $\begin{array}{c}\text { Attack } \\
\text { Initiated } \\
\%\end{array}$ & $\begin{array}{c}\text { Attack } \\
\text { Propagating } \\
\text { to } 0.25 \mathrm{~mm}, \%\end{array}$ & $\begin{array}{c}\text { Maximum Depth } \\
\text { of Attack, } \\
\text { mm }\end{array}$ \\
\hline $2200^{\circ} \mathrm{F}\left(1204^{\circ} \mathrm{C}\right)$ & 0 & 0 & 0 \\
$1600^{\circ} \mathrm{F}\left(871^{\circ} \mathrm{C}\right)^{\mathrm{b}}$ & 17.5 & 0 & 0.02 \\
\hline
\end{tabular}

${ }^{a}$ Private communication, International Nickel Co., Inc.

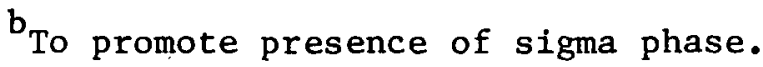

TABLE II. Results of Exposure to $10 \% \mathrm{FeCl}_{3}$ for 72 Hours at Room Temperature

\begin{tabular}{cccc}
\hline Alloy & $\begin{array}{c}\text { Weight Loss, } \\
\%\end{array}$ & $\begin{array}{l}\text { Crevice } \\
\text { Attack }\end{array}$ & P1tt1ng \\
\hline 304 & 2.5 to 5.1 & Severe & Severe \\
316 & 2.5 to 5.1 & Severe & Severe \\
317 & 0.8 to 1.1 & - & - \\
$29 \%$ Cr 4\% Mo & 0 & 0 & 0 \\
$26 \%$ Cr 1\% Mo & 0 & 0 & 0 \\
A1-6X & 0 & 0 & 0 \\
Titanium & 0 & 0 & 0 \\
\hline
\end{tabular}


TABLE III. Critical Crevice Corrosion Temperatures

in $10 \% \mathrm{FeCl}_{3} \mathrm{pH} 1$

\begin{tabular}{|c|c|c|}
\hline Alloy & $\begin{array}{c}\text { Temperature of } \\
\text { No Crevice } \\
\text { Corrosion, } \\
{ }^{\circ} \mathrm{C}\end{array}$ & $\begin{array}{c}\text { Temperature of } \\
\text { slight Crevice } \\
\text { Corrosion, } \\
{ }^{\circ} \mathrm{C}\end{array}$ \\
\hline $\begin{array}{l}304 \\
316 \mathrm{~L}(17 \% \mathrm{Cr} 12 \% \mathrm{Ni} 2.5 \% \mathrm{Mo}) \\
27 \% \operatorname{Cr} 1.5 \% \mathrm{Mn} 4 \% \mathrm{Ni} \\
25 \% \mathrm{Cr} 3.5 \% \mathrm{Mo} \\
26 \% \text { r.r } 1 \% \mathrm{Mn} \\
\text { AL- } 6 \mathrm{X}\end{array}$ & $\begin{array}{c}- \\
- \\
5 \\
47.5 \\
20-22.5 \\
17.5-20\end{array}$ & $\begin{array}{c}-.2 .5 \\
0 \\
7.5 \\
50 \\
22.5-25 \\
20-22.5\end{array}$ \\
\hline
\end{tabular}

TABLE IV. Breakthrough Potential Tests of Stainless Steels in Chloride Solutions

\begin{tabular}{ccc}
\hline & \multicolumn{2}{c}{ Minimum Breakthrough Potential, mV } \\
\cline { 2 - 3 } Alloy & 1000 ppm Chloride & 10,000 ppm Chloride \\
\hline 304 & 220 & 180 \\
316 & 330 & 250 \\
Al.-6X & $1000+^{\mathrm{a}}$ & 940 \\
\hline
\end{tabular}

${ }^{a}$ Beyond range of test. 
TABLE V. Results of Multiple Crevice Corrosion Test in Flowing Sea Water in Ambient Temperatures at Harbor Island, North Carolina for Five Years

\begin{tabular}{|c|c|c|c|c|c|c|}
\hline \multirow[b]{3}{*}{ Alloy } & \multirow{3}{*}{$\begin{array}{l}\text { Average } \\
\text { Weight } \\
\text { Loss, g }\end{array}$} & \multicolumn{5}{|c|}{ Probability, $\%$} \\
\hline & & & 10 mils & 50 mils & Max. & Depth \\
\hline & & Initiation & $(0.25 \mathrm{~mm})$ & $(1.25 \mathrm{~mm})$ & mils & $\mathrm{mm}$ \\
\hline & & & & & & \\
\hline $316^{a}$ & 0.14 & 6 & 6 & 0 & 38 & 0.95 \\
\hline$A L-6 \mathrm{X}$ & 0.01 & 0 & 0 & 0 & 0 & 0 \\
\hline
\end{tabular}

${ }^{a}$ Tested for 126 days.

TABLE VI. AL-6X Installations

\begin{tabular}{|c|c|c|}
\hline Company & P1ant & Date \\
\hline United Illuminating. & $\begin{array}{l}\text { Bridgeport Harbor No. } 1 \\
\text { Bridgeport Harbor No. } 2\end{array}$ & $\begin{array}{l}1973 \\
1976\end{array}$ \\
\hline Tampa Electric & $\begin{array}{l}\text { Big Bend No. } 1 \\
\text { Hooker's Point No. } 5 \\
\text { Gannon No. } 6\end{array}$ & $\begin{array}{l}1976 \\
1976 \\
1977\end{array}$ \\
\hline $\begin{array}{l}\text { Public Service Elec: \& Gas } \\
\text { New Jersey }\end{array}$ & $\begin{array}{l}\text { Linden } \\
\text { Sewaren }\end{array}$ & $\begin{array}{l}1977 \\
1978\end{array}$ \\
\hline New Orleans Public Service & $\begin{array}{l}\text { Michoud No. } 3 \\
\text { Michoud No. } 2\end{array}$ & $\begin{array}{l}1977 \\
1978\end{array}$ \\
\hline Long Island Lighting & $\begin{array}{l}\text { Northport No. } 1 \\
\text { Northport No. } 2\end{array}$ & $\begin{array}{l}1978 \\
1979\end{array}$ \\
\hline New England Electric & $\begin{array}{l}\text { Brayton Point No. } 1 \\
\text { Brayton Point No. } 2\end{array}$ & $\begin{array}{l}1978 \\
1978\end{array}$ \\
\hline Maine Yankee & & 1978 \\
\hline
\end{tabular}


TABLE VII. Galvanic Series in Sea Water for Alloys of Interest in OTEC Systemsa

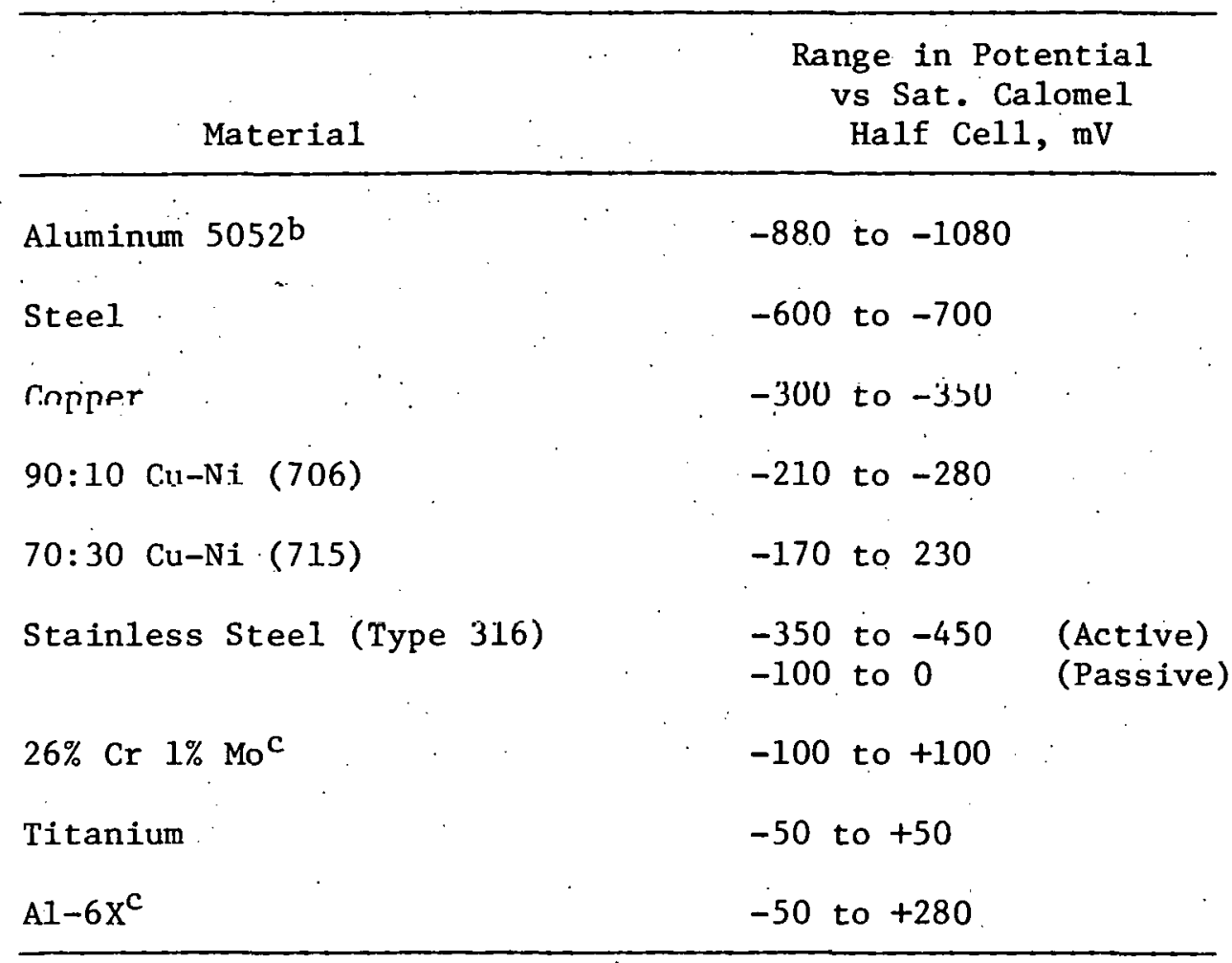

${ }^{a}$ From Marine Corrosion, John Wiley and Sons, Inc., 1975, Fig. 6-1.

brom T. J. Lennox, Jr., Naval Research Laboratory Report 3622, 1977.

From T. J. Lennox, Jr. and M. H. Peterson, NACE Corrosion/76, Houston, Texas, March 1976, paper 78. 
TABLE VIII. Results of Tests in Sea Water Moving at High Velocity

TEST 1. Specimens on Rotation Disc at Tip Velocity of $27 \mathrm{ft} / \mathrm{sec}$ $(8.2 \mathrm{msec})$ for 60 Days at $16^{\circ} \mathrm{C}\left(61^{\circ} \mathrm{F}\right)$. Exposed area $7.2 \mathrm{in} .^{2}\left(46 \mathrm{~cm}^{2}\right)$.

\begin{tabular}{lcr}
\hline \multicolumn{1}{c}{ Alloy } & $\begin{array}{c}\text { Weight Loss, } \\
\text { g }\end{array}$ & Appearance \\
\hline $\begin{array}{l}\text { IN-748 } \\
316 \text { Stainless Steel }\end{array}$ & 0.004 & No visible corrosion \\
\hline
\end{tabular}

TEST 2. Extreme Velocity Test ${ }^{c}$ Test Velocity $129 \mathrm{ft} / \mathrm{sec}^{\mathrm{d}}$ (39 msec)

for 30 Days at $9^{\circ} \mathrm{C}\left(48^{\circ} \mathrm{F}\right)$. Exposed area $3.5 \mathrm{in} . .^{2}\left(22 \mathrm{~cm}^{2}\right)$.

\begin{tabular}{lcl}
\hline Alloy & Weight Loss, & \\
\hline $\mathrm{g}$ & Cavitation Damage \\
\hline IN-748 Stainless Steel & 0.04 & Trace \\
& 0.03 & None \\
\hline
\end{tabular}

TEST 3X. Extreme Velocity Test ${ }^{c}$ Test Velocity $130-140 \mathrm{ft} / \mathrm{sec}$ (40 msec) for 30 Days at $15^{\circ} \mathrm{C}\left(59^{\circ} \mathrm{F}\right)$.

\begin{tabular}{lcc}
\hline \multicolumn{1}{c}{ Alloy } & \multicolumn{2}{c}{ Corrosion Rate } \\
\cline { 2 - 2 } mils/yr & mm/yr \\
304 Stainless Stee1 & 1 & 0.025 \\
316 Stainless Stee1 & 1 & 0.025 \\
$90: 10$ Cu-Ni (CA-706) & 25 & 0.63 \\
6061 Aluminum & 65 & 1.6 \\
Carbon Stee1 & 150 & 3.8
\end{tabular}

anternational. Nickel Co., Inc., private communication, 1977.

${ }^{b}$ See F. L. LaQue, Marine Corrosion, John Wiley and Sons, Inc., New York, Fig. 3.14, p. 59, 1957.

${ }^{c}$ See F. L. LaQue, Marine Corrosion, John Wiley and Sons, Inc., New York, Figs. 3.22 to 3.25, p. 64,1957 .

$\mathrm{d}_{\mathrm{Hole}}$ in specimen to induce cavitation. 


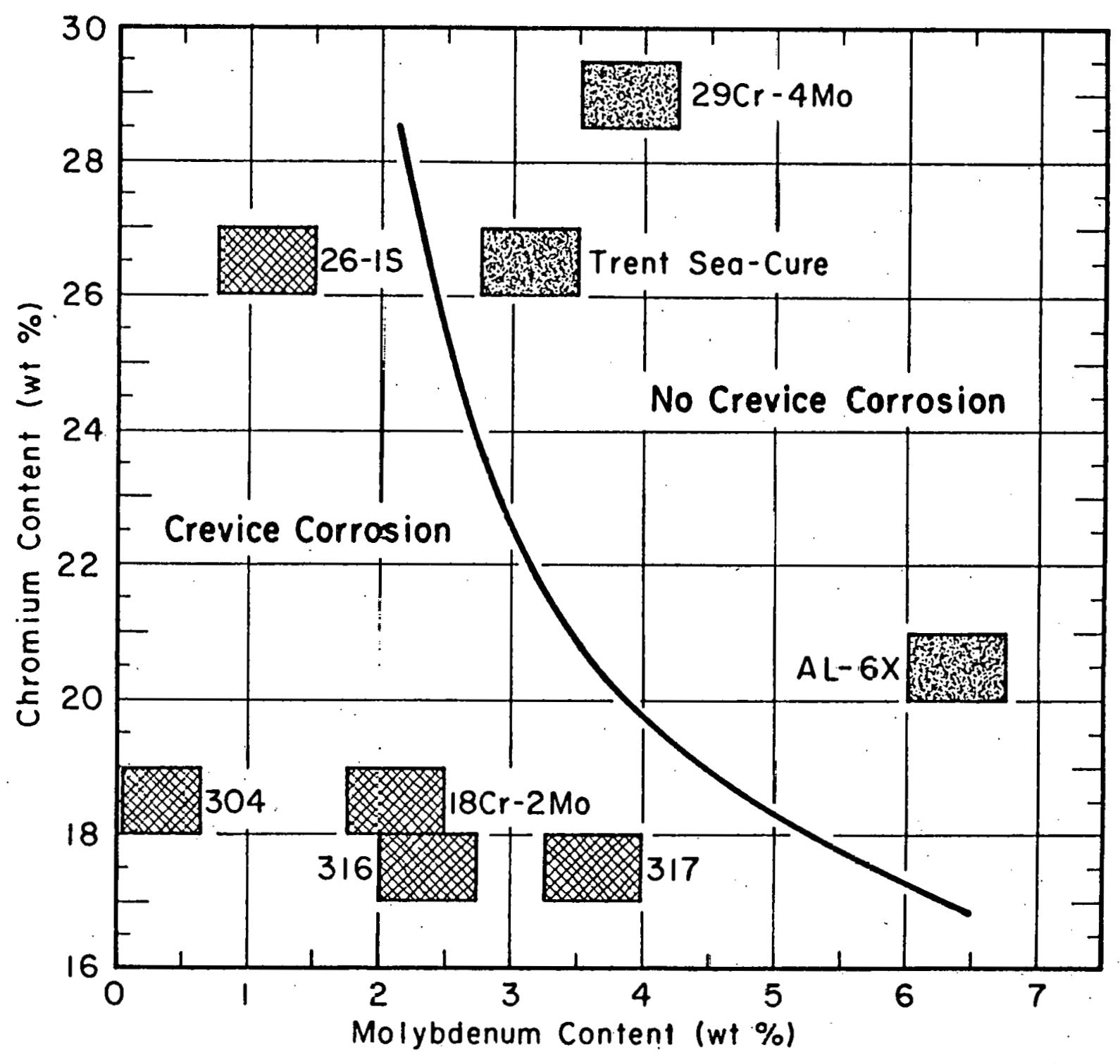

Figure 1. Susceptibility of Alloys to Crevice Corrosion as a Function of Chromium and Molybdenum Content 


\section{REFERENCES}

1. G. W. Marsha11, Combustion, 48(5), 14-17 (1976).

2. N. A. Long, American Power Conference, Chicago, 1966.

3. N. A. Long, Fourth Steel Congress, Luxenbourg, July 1968.

4. D. W. Haskinson and C. K. Kuester, ASME Series A, J. Eng. for Power, 87, 401-404 (1965).

5. R. J. Brigham and E. W. Tozer, Canadian Metallurgical Quarterly, 12(2), $171-176$ (1973).

6. T. J. Lennox, Jr. and M. H. Peterson, NACE Corrosion/76, Houston, TX, March 1976, paper 78.

7. D. B. Anderson, American Society for Testing and Materials, ASTM STP 576, 1976, pp. 231-242.

8. H. Smith, Metal Progress, 33, 596-600 (1938).

9. R. J. Brigham and E. W. Tozer, Corrosion 29(1), 33-36 (1973).

10. R. J. Brigham, Corrosion 30(11), 396-398 (1974).

11. A. P. Bond, H. J. Dundas, S. Ekerot, and M. Semchysen, Stainless Steel 77, London, England.

12. M. Fujii and M. Kumada, Japan Institute of Meta1s, 34, 6 (1970).

13. H. E. Deverell and J. R. Maurer, NACE Corrosion/77, San Francisco, CA, paper 97.

14. J. R. Maurer, Allegheny Ludlum Steel Co., private communication (1977).

15. International Nickel Co., Inc., private communication (1977).

16. H. R. Copson in Physical Metallurgy of Stress Corrosion Fracture, edited by T. Rhodes, Wiley Interscience, New York, 1959, p. 247.

17. C. W. Kovach, Inco Power Conference, Wrightsville Beach, North Carolina, August 1978 。 


\section{SUPPLEMENTARY REFERENCES}

J. M. Defranoux, Journee Des Aciers Speciaux und L'Eau De Mer, Conference International Des Arts Chimiques, 1962, p. 10.

J. M. Vassal et H. Vernon, Ibid., p. 33 .

M. Hockman, Ibid.

M. Pourbaix, et al., Corrosion Science, 3, 239 (1963).

H. P. Leckie and H. H. Uhlig, J. Electrochem. Soc., 113 (12), 1262 (1966).

F. W. Fink, E. L. White and W. K. Royd, Report to U. S. Dept. of Interior, orfice of Saline Water, June 1966.

V. N. Gulyaev, et al., Therm. Eng., 14 (12), 45-49 (1967).

E. H. Phelps, R. T. Jones, and H. P. Leckie, J. Electrochem. Soc., 116 (6), 213C-217C (1969).

Y. Korovin and I. B. Ulanovsky, Zaschita Metallov, , 1 (6), 9-13 (1970).

B. E. Wilde, Corrosion, 28 (8), 283-291 (1972)。

D. W. C. Baker, W. E. Heaton, and B. C. Patient, Corrosion Science, 12, 247-2.64 (1.972).

W. H. Richardson, P. Guka, and R. Machin, Proc. Third Int. Congress on Marine Corrosion and Fouling, 1972, p. 528.

K. Shiobara and S. Moricka, J. Japan Inst. Metals, 36, 5 (1972).

T. J。 Lennox, Jr。 and M. H. Peterson, Offshore Technology Conf., 1972, paper 1580.

E. S. Kopecki, Chen, Eng., 80, 124 (January 22, 1973).

H. H. Lawson, S. E. Doughty and R. T. Jones, NACE Corrosion/73, Anaheim, CA, March 1973, paper 59.

G. Lennaitz and E. Michel, D. E. W. Tech., Ber 13 (2), 101-107 (1973).

N. Pessall and J. I. Nurminen, NACE Corrosion/73, Anaheim, CA, March 1973, paper 65.

R. A. Lular, 6th Annual offshore Technology Conf., Houston, TX, 1974, paper OTC 1961.

M. A. Streicher, Corrosion, 30 (4), 115-124 (1974).

S. Henrikson and L. Knutson, British Corrosion Journal, 10 (3), 128-135 (19.75). 
U. S. Dept. of Interior, Office of Water Research and Technology, Desalination Materials Manual, May 1975.

S. Brennert and G. Lendk, Proc. Scandinavian Corrosion Congress, 1975, pp. 346-355.

K. D. Efird, Proc. 6th Int. Congress on Metallic Corrosion, Sydney, Australia, December 1975.

M. Keyoshige, et a1:, Trans. I. I. J. Japan, 15, 508-515 (1975).

R. J. Brigham, NACE Corrosion/75, Toronto, Canada, April 1975, paper 158.

J. M. Defranoux, et al., Pub. Cent. Nat1. Exploit Oceans, 3, 379-389 (1975).

R. J. Brigham and E. W. Tozer, Corrosion, 32 (7) 274-276 (1976).

R. Casset, E. Chassin, H. Coriou, L. Grall, and C. Mahieu, 5th International Symposium on. Fresh Water from the Sea, 1 , 359-364 (1976).

H. Brandis, H. Kiesheyer, and G. Lennaritz, D. E. W. Tech., Ber 2 (1) $14-18$ (1976).

K. Kato, et a1., Denki Seiko, 47 (2), 70-77 (1976).

M. Kowaka, et al., Sumitomo Search No. 16, November 1976, pp. 64-77.

Nickel Topics, International Nickel Co., Inc., 1977.

J. E. Truman, Corrosion Science, 17, 737-746 (1977).

R. M. Davison, Mosaic, Amax, 1977.

A. P. Bond, H. J. Dundas, S. Ekerot, and M. Semchyshen, Stainless Steel 77, Climax Molybdenum Co., pp. 197-211.

Localized Corrosion, Int. Conf. on Localized Corrosion, Williamsburg, VA, NACE, 1978. 
Interna1:

J. E. Draley (5)
B.R.T. Frost
R. G. Matlock
N. F. Sather
A. Thomas

Externa1:

J. Hilbert Anderson, Sea Solar Power, Inc.

W. H. Avery, Applied Physics Laboratory, Johns Hopkins University

Roderick A. Barr, Hydronautics, Inc.

E. Barsness, Westinghouse Electric Corporation

N. Basar, M. Rosenblatt \& Son, Inc.

James 0. Bates, Ënergy Technology Engineering Center

Kenneth J. Bell, Oklahoma State University

Robert A. Bonewitz, Aluminum Company of America

R. Cohen, US-DOE, Div. of Central Solar Technology

William A. Corpe, Columbia University

G. J. Danek, Annapolis, Maryland

James Denton, TRW Systems and Energy

John DePalma, U. S. Naval Oceanographic Office

Stephen Dexter, University of Delaware

Richard Drisko, Civil Engineering Laboratory

John G. Fetkovich, Carnegie-Mellon University

Malcom D. Fraser, Intertechnology Corp.

Derek P. Gregory, Institute of Gas Technology

Sigmund Gronich, US-DOE, Div. of Central Solar Technology

E. C. Haderlie, Naval Postgraduate School

P. H. Hadley, Jr., Gibbs \& Cox, Inc.

A. J. Haskel, Society of Naval Architects and Marine Engineering

William E. Heronemus, University of Massachusetts

Duane T. Hove, Science Applications, Inc.

F. K. Hill, Applied Physics Laboratory, Johns Hopkins University

Jules Hirshman, Tracor Marine

J. F. Jenkins, Civil Engineering Laboratory

George Jensen, Battelle Laboratories

Gerhard $\overline{\mathrm{H}}$. Jirks, Massachusetts Institute of Technology

E. H. Kinelski, US-DOE, Div. of Central Solar Technology

James G. Knudsen, Oregon State University

Robert E. Lacey, Southern Research Institute

Abrahim Lavi, Carnegie-Mellon University

T. S. Lee, International Nicke1 Company

Murray Leitner, Lockheed Missiles and Space Co., Inc.

Lloyd Lewis, US-DOE, Div. of Central Solar Technology

Brenda Little, NORDA

Thomas E. Little, Westinghouse Electric Corporation

D. Lott, Naval Coastal Systems Center

Richard N. Lyon, Oak Ridge National Laboratory

R. Markofski, Applied Physics Laboratory, Johns Hopkins University

Frank Mathews, Colorado School of Mines

James W. Mavor, Jr., Woods Hole Oceanographic Institution 
W. R. McCluney, Florida Solar Energy Center

Michael McCormick, U. S. Naval Academy

William F. McIlhenny, DOW Chemical

John W. Miche1, Oak Ridge Nationa1 Laboratory

Ralph Mitche11, Harvard University

Robert L. Molinari, NOAA/AMOL

John Morse, University of Miami

Fred C. Munchmeyer, University of Hawaii

John Nicol, Arthur D. Little, Inc.

Jack M. Nilles, University of Southern California

Edward K. Noda, Research Corporation, University of Hawaii

Merle 01msted, General Electric Company

T. B. O'Neill, Civil Engineering Laboratory

David Price, U. S. National Oceanic and Atmospheric Administration

J. F. Rynewicz, Lockheed Missiles and Space Cọ., Inc.

Cullen M. Sabin, Geoscience, Ltd.

Donald Sasscer, U. of Puerto Rico

H. H. Sephton, University of California at Berkeley

William Sheppard, NOAA Data Buoy Office

Wilbur Sherwood, US-DOE, Div, of Central Solar Technology

Eugene Silva, Naval Facilities Engineering Command

J. E. Snyder, TRW Systems and Energy

Frank Spiehler, NOAA Data Buoy office

W. R. Suratt, DSS Engineers, Inc.

Edward J. Tachupp, General Electric Company/TEMPO

R. B. Teel, Chatham, New Jersey

D. L. Thomas, Radiation Management Corporation

Ortwin Von Zweck, Florida Institute of Technology

Fred Vukovich, Research Triangle Institute

J. Paul Walsh, Value Engineering Company

Gerald Wick, University of Californta at San Diego

Ralph Williams, PRC Energy Analysis Co.

David C. White, Florida State University

Hank White, University of Hawaii

Paul Wolff, Ocean Data Systems, Inc.

DOE-TIC, for distribution per UC-64 (412)

Manager, Chicago Operations Office

Chief, Office of Patent Counsel, $\mathrm{CH}$

President, Argonne Universities Association 